\title{
What is First? Metaphysics as Prima Philosophia and Ultima Scientia in the Works of Thomas Aquinas
}

\author{
Jan Kielbasa
}

Received: 5 February 2013 /Revised: 5 April 2013 / Accepted: 14 April 2013 /

Published online: 17 August 2013

(C) The Author(s) 2013. This article is published with open access at Springerlink.com

\begin{abstract}
The article analyzes the status of metaphysics in relation to other sciences, especially the sense and reasons behind its priority in the system of sciences, as conveyed in the works of Thomas Aquinas. The question of what comes first in the system of sciences has led to an exploration and justification of the criteria behind this priority. According to Thomas Aquinas, metaphysics is justly considered to be the first philosophy: on the one hand it is occupied with what comes first in the ontological order - the first causes of being, on the other hand, other sciences rely on it for their first principles. The article critically analyzes both substantiations of the idea of being first. The substantive criterion is questioned by the introduction of revealed theology into the system of sciences accepted by Aquinas; revealed theology is also occupied with what comes first, and does so with greater authority than metaphysics. The article focuses on the analysis of main doubts concerning metaphysics' methodological criterion of priority: the idea that metaphysics, in relation to other sciences, is in a sense first and functions as a determinant, while also being last and determined by these very sciences. Metaphysics is first, as other sciences draw from it their first principles, and last, as it utilizes facts established by other sciences which come first in the process of knowledge acquisition. Hence the charge that Aquinas' argumentation concerning metaphysics' priority is circular in nature. The article analyzes various aspects of this difficulty and offers suggestions on how to overcome them.
\end{abstract}

Keywords Circular reasoning · First philosophy · First principles · Metaphysics · Philosophical theology · Priority · Theoretical science

The philosophical question of what comes first - perhaps a naive question, and simultaneously one of the uttermost significance - surely requires an elementary understanding of what it means for something to be first. We can ask whether some

J. Kielbasa $(\square)$

Institute of Philosophy, Jagiellonian University, Grodzka st. 52, 31 - 044 Cracow, Poland

e-mail: jan.kielbasa@uj.edu.pl 
objects meet the criteria for being "the first things". These criteria might be diverse and antagonistic: ordinary chronological antecedence, ontological precedence, the cause in a causal interaction, elementariness or maximal structural simplicity, perfection or complete actualization, the highest level of axiological qualification, etc. We may also ask this question about the conceptual realm and look for the "primary concepts'. In this case the criteria of precedence may also be various and conflicting, e. g. the inability to be reduced to something simpler, maximum extension, generality, obviousness, certainty, etc. Yet I shall attempt to answer the question "What is first?" mainly in relation to the status of classic metaphysics, as confronted with other areas of science. As the title of the article suggests, my analysis will pertain to the "localization" of metaphysics within the system of human knowledge conducted by Thomas Aquinas. According to the beliefs of the Medieval philosopher, the system of knowledge encompasses mathematics as well as ethics, natural sciences as well as theology. The dialectics of what is first and what follows later (or what comes in the end) in relation between metaphysics and sciences that have been termed "theoretical" since the times of Aristotle, shall be of focal significance for me. While investigating this specific dialectics I hope to disclose what Thomas Aquinas meant by metaphysics as the first and simultaneously the last philosophy (prima in dignitate, ultima in addiscendo, first in dignity, last in the order of learning), while also revealing the difficulties faced by those who ask: "What is first" in this particular context.

It seems to me that when we ask the question of what is first in the context of historical discussions concerning the status of metaphysics as the first philosophy (and thus the last science), we must inevitably tackle one of the most problematic aspects of the issue: the assumed "circularity" of arguments pertaining to the relationship between metaphysics and other sciences. Source literature provides evidence that Thomas Aquinas was well aware of the fact that these arguments are not obviously correctand that he attempted - with lesser or greater success - to overcome the difficulties stemming from them. Yet the sources of these difficulties and the first proposals of viewing the paradox of metaphysics' being both the first and the last in the system of sciences as only apparent should be sought, in my opinion, in the works of Avicenna. This Arabian philosopher and scholar was the heir to both momentous traditions of Greek philosophy (Aristotelian and neo-platonic) and he inspired the development of many philosophical concepts in Western Europe. It was Avicenna who perceived in the early 11th century (according to Western calculations) that the arguments in question contain circular reasoning, as on the one hand metaphysics is qualified as the first philosophy (especially in the sense that it is the most fundamental of sciences, one from which other sciences draw their first and most undeniable principles), and on the other hand metaphysics is considered to be a final science in the order of knowledge acquisition and teaching, absorbed subsequently to other fields of science (what - as was commonly thought - stems from the very meaning of the term "metaphysics"). In his encyclopedic Book of Healing, known to Western scholars as Metaphysica, as this was its name in Latin translation, Avicenna presented the problem in the following manner: Someone might object by stating that since the principles of natural and mathematical sciences are proven only within this science, and the questions posed by both types of sciences are proven by its principles, while the stated questions in turn become the principles of the aforementioned science, then 
the argumentation is circular and proceeds with the help of that which comes at the end ${ }^{1}$.

Thus the "circularity" spotted by Avicenna lies in the fact that metaphysics is deemed to be the source and test of the first principles of other sciences (so-called particular sciences, especially natural sciences - scientiae naturales, as well as "liberated" sciences - scientiae disciplinales); these sciences draw the validity of their assumptions from metaphysics, while simultaneously these very assumptions are seen reversibly as the principles of or the inspiration for metaphysics itself. The particular sciences provide 'first philosophy' with the knowledge that is strictly required to undertake the study of metaphysics. If the far-reaching consequences of metaphysics (the assumptions of other sciences) are simultaneously held to be its primary principles (and - in return - if the primary principles are to be supplied to other sciences by metaphysics as a discipline that itself is already based upon them), then we do, in fact, come across a logical error, namely, typical circular reasoning.

Yet Avicenna explains in detail how we can avoid this objection. My reconstruction of his argumentation allows me to suggest the following solutions: first of all, the principle of a given science does not have to be a principle on which all current and potential reasoning or assumptions depend, i.e. something upon which all argumentation pertaining to the entire science is based; it is enough that the principle proves and resolves a limited number of matters. Secondly, sciences include matters that do not need to be proven by appealing to principles stemming from other sciences, and especially principles guaranteeing full and certain knowledge about a given phenomenon (indicating its causes); this is the case when arguing that a given thing exists (an est) without proving why it exists (quare est). Thirdly, both metaphysics and other sciences have at their disposal their own axioms - autonomous principles that are implicitly obvious and thus do not have to be confirmed by other, more primary (or first) principles, nor derived from them.

Avicenna thus assumes that certain principles pertaining to natural sciences can be implicitly obvious, due to which they need not be previously proven on the grounds of metaphysics. These autonomous principles of natural sciences in turn are delivered to metaphysics but do not condition its first principles, as these are also autonomous. Thus it is not true that metaphysics had previously derived conclusions from other sciences - the sciences that it provides first principles for - so that other sciences may draw from metaphysics the principles for which they are to provide crucial data. In reference to the above, Avicenna's argumentation concerning metaphysics as the first philosophy, which provides first principles to other sciences, and simultaneously a science which supersedes these sciences and benefits from their assumptions, is not circular; it is not based on argumentation which includes content that is being augmented for (and which must prove itself): It is thus stated that since this is so, then in no manner is the aforementioned proof circular in the sense that it assumes something identical to what is being proven ${ }^{2}$.

\footnotetext{
${ }^{1}$ Metaphysica, tract. 1, cap. 3: Potest autem aliquis opponere dicens quod si principia scientiae naturalis et disciplinalium non probantur nisi in hac scientia et quaestiones utrarumque scientiarum probantur per principia earum, quaestiones vero earum fiunt principia huius, tunc haec argumentatio est circularis et per ultimum eius fit manifestatio sui ipsius [Avicenna (1977)].

${ }^{2}$ Metaphysica, tract. 1, cap. 3: Constat igitur quod, cum ita sit, non erit praedicta probatio circularis ullo modo, ita ut ipsa sit probatio in qua aliquid idem accipiatur in probatione sui ipsius [Avicenna (1977)].
} 
From Avicenna's point of view, additional support for the above argumentation is the statement that natural sciences, based on their own principles, supply direct and simple knowledge concerning the subject of whether something exists (an est), but do not allow us to attain more refined knowledge - they do not let us find out why something exists (quare est). This complementary knowledge of the "higher realm" especially in reference to distant, not directly disclosed final causes - may be revealed only with methods inherent to metaphysics. The autonomy relating to subject matter of both these fields of knowledge is further augmented by the relative autonomy of principles and prevents mutual conditioning to materialize in the form of a vicious circle. It is also confirmed that - due to the rank of metaphysics' subject matter - it deserves the position of the first philosophy, prevailing over other sciences (altior omnibus scientiis), despite the fact that in the order of knowledge assimilation it follows after all other sciences (posteriatur post omnes scientias), inter alia due to the fact that grasping the causes of existence must be preceded by knowledge of existence itself.

In his commentary to Boethius's De Trinitate, Thomas Aquinas also refers to the issue of assumed "circularity" of arguments pertaining to the relationship between metaphysics and other sciences. Although metaphysics, understood here as scientia divina, is objectively (naturaliter) first among all other sciences (prima omnium scientiarum), when it comes to human knowledge, i.e. the order of knowledge acquisition, other fields of science are first (quoad nos aliae scientiae sunt priores). These sciences establish many varieties of truth required and utilized by metaphysics in its argumentation. For example, natural sciences establish what is meant by coming into being and perishing, and astronomy, seen as a science comprising the quadrivium and founded on comprehensively understood mathematical knowledge, establishes as Thomas believed, following the examples of Aristotle and Avicenna - the number and order of heavenly realms. All these conclusions are beneficial to metaphysics, just as the data supplied by the "liberated sciences" (artes liberales) and - to a smaller degree - practical sciences (scientiae morales). Yet, on the other hand, Thomas does not doubt the hypothesis proposed by Avicenna: that metaphysics is the first philosophy also because it is in a sense fundamental for other sciences, as the latter draw their first principles from the former. This, prima facie, resembles circular reasoning. Yet Thomas clearly attempts to avoid such a conclusion: Nor is there necessarily a vicious circle because metaphysics presupposes conclusions proved in the other sciences while it itself proves their principles. For the principles that another science (such as natural philosophy) takes from first philosophy do not prove the points which the first philosopher takes from the natural philosopher, but they are proved through other self-evident principles. Similarly the first philosopher does not prove the principles he gives the natural philosopher by principles he receives from him, but by other self-evident principles. So there is no vicious circle in their definition ${ }^{3}$.

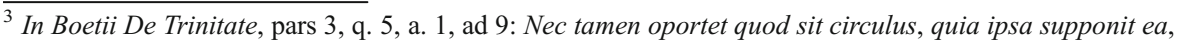
quae in aliis probantur, cum ipsa aliarum principia probet, quia principia quae accipit alia scientia, scilicet naturalis, a prima philosophia, non probant ea quae idem primus philosophus accipit a naturali, sed probantur per aliqua principia per se nota. Et similiter philosophus primus non probat principia, quae tradit naturali, per principia quae ab eo accipit, sed per aliqua principia per se nota. Et sic non est aliquis circulus in definitione [Thomae de Aquino (1959)].
} 
It seems that Thomas portrays Avicenna's reasoning in a briefer and slightly clearer form: the fact that metaphysics as the first philosophy provides first principles to other sciences, and that these first principles have their foundations and confirmation in metaphysics, as well as the fact that metaphysics is the final knowledge, succeeding other sciences and thus drawing from them any conclusions it may require, does not have to indicate a vicious circle. It can be that principles acquired from metaphysics as the first philosophy by a different science (e. g. physics) are not used to prove matters or argue conclusions that this science in turn delivers to metaphysics (first philosophy), as these conclusions are proven with the help of other principles that are implicit (and not drawn from other sciences, in this case metaphysics). Similarly, metaphysics as the first philosophy does not prove principles it provides to other sciences (e.g. natural sciences) with the help of principles or conclusions that it has itself drawn from them, but does so with the help of other principles that are implicit. This way, the argumentation does not take the form of a vicious circle. I understand Aquinas's polemic argumentation, formulated to deflect the above objection, as follows: it attempts to prove both the full autonomy of metaphysics' primary principles in relation to exact sciences and at least in part the autonomy of research and results of these sciences in relation to metaphysics' primary principles. I thus suggest to combine and assess as equally legitimate both manners of interpreting the sense of the quoted commentary, which are presented as distinct and unequivalent (from the point of view of the effectiveness of argumentation deflecting the objection of circularity) by John F. Wippel in his in-depth study of the issue ${ }^{4}$. It is thus enough to draw attention to the non-identity of principles supplied by metaphysics to other sciences and the principles used by these sciences when making conclusions that are subsequently offered to metaphysics. Of course, this means that the full set of principles used by other sciences has not been provided by metaphysics. Among these there is a separate group - principles that are implicitly obvious, i.e. they draw their certainty from the very meaning of the terms they are formulated with (and this is why they do not need to be guaranteed by other sciences, i.e. metaphysics). Similarly, other sciences, especially natural sciences, do not provide a full set of principles required by metaphysics, those utilized by metaphysics and delivered to other sciences; other sciences may have their own, autonomous sources (again, these may be implicit), and do not have to be derived from the content supplied to metaphysics by exact sciences.

The argument is further augmented, in the same commentary, by an exploration of what is really first, and in what sense it is "first" in our perception": Moreover, the sensible effects on which the demonstrations of natural science are based are more evident to us in the beginning. But when we come to know the first causes through them, these causes will reveal to us the reason for the effects, from which they were proved by a demonstration "quia". In this way natural sciences also contribute something to divine

\footnotetext{
${ }^{4}$ Cf. John F. Wippel, Aquinas and Avicenna on the Relationship between First Philosophy and the other Theoretical Sciences (in:) J.F. Wippel, Metaphysical Themes in Thomas Aquinas, part I, chapter II, Washington 1984, p. 37-54 (especially 46-48). Important remarks about the possible meanings of metaphysic's priority can also be found in the following chapter (First Philosophy according to Thomas Aquinas), ibidem, p. 55-67

${ }^{5}$ It is in this context that Wippel speaks of distinguishing the order of nature and the order of discovery. Cf. John F. Wippel, Aquinas and Avicenna on the relationship..., op. cit., p. 43
} 
science, and nevertheless it is divine science that explains their principles. That is why Boethius places divine science last, because it is the last relative to us ${ }^{6}$.

Additionally, Thomas argues that the consequences captured by the senses appear at first to be more obvious, of course, as we have more knowledge of them; basing on these consequences, natural sciences perform their intrinsic reasoning, in the form of "thus" (quia). Yet since we come to know the primary causes thanks to this reasoning, then we unlock the answers to "because of what" (propter quid) these consequences appear, based on these selfsame primary causes. This way natural sciences supply "scientia divina" to metaphysics, and in turn thanks to metaphysics the principles of these sciences are confirmed, while the conclusions drawn from them are understandable and valid. Thus the type of cognition intrinsic to metaphysics (propter quid), i.e. cognition of the primary causes, is reached later and with the help of cognition intrinsic to natural sciences (quia), i.e. cognition of effects as captured by the senses (as these are prima facie more obvious to us and accessible with greater ease). Yet only in the light of grasping the first causes (and so in the light of knowledge gained through metaphysics), in the light of propter quid, the effects captured by the senses (with which natural sciences are occupied) do gain their proper foundations, explanations and substantiation.

In a different fragment of his commentary to Boethius's De Trinitate, Thomas suggests a different approach to the relationship between metaphysics (understood as philosophia prima and scientia divina) and other sciences, especially natural sciences (philosophia naturalis). He explains the relationship from the angle of intellectual premise inherent to each of these sciences, and their inherent methods: Just as we attribute the rational method to natural philosophy because it adheres most closely to the method of reason, so we attribute the intellectual method to divine science because it adheres most closely to the method of intellect ${ }^{7}$. The problem of "circularity" of argumentation appears when intellectual considerations inherent to metaphysics are deemed to be the beginning and principle of rational considerations (principium rationalis considerationis), inherent to other sciences (including natural sciences), and are simultaneously thought of as the extremity, the final point of rational considerations (terminus rationalis considerationis): It also follows that divine science gives principles to all the other sciences, because intellectual thinking is the starting point of rational thinking; and for this reason it is called first philosophy. Nevertheless it is learned after physics and the other sciences, because intellectual thinking is the terminus of rational thinking. For this reason it is called metaphysics, as if to say beyond physics, for in the process of analysis it comes after physics ${ }^{8}$.

\footnotetext{
${ }^{6}$ In Boetii De Trinitate, pars 3, q. 5, a. 1, ad 9: Preterea, effectus sensibiles, ex quibus procedunt naturales demonstrationes, sunt notiores quoad nos in principio. Sed cum per eos pervenerimus ad cognitionem causarum primarum, ex illis apparebit nobis « propter quid» illorum effectuum, ex quibus probantur demonstrationes « quia ». Et sic scientia naturalis aliquid tradit scientiae divinae, et tamen per eam sua principia notificantur. Et inde est quod Boetius ponit ultimo scientiam divinam, quia est ultima quoad nos [Thomae de Aquino (1959)].

${ }^{7}$ In Boetii de Trinitate, pars 3, q. 6, a. 1, c - ad tertiam quaestionem: Sicut rationabiliter procedere attribuitur naturali philosophiae, quia in ipsa observatur maxime modus rationis, ita intellectualiter procedere attribuitur divinae scientiae, eo quod in ipsa observatur maxime modus intellectus [Thomae de Aquino (1959)].

${ }^{8}$ In Boetii De Trinitate, pars 3, q. 6, a. 1, c: Et inde etiam est quod ipsa largitur principia omnibus aliis scientiis, in quantum intellectualis consideratio est principium rationalis, propter quod dicitur prima philosophia. Et nihilominus ipsa addiscitur post physicam et cetereas scientias, inquantum intellectualis consideratio est terminus rationalis, propter quod dicitur metaphysica quasi transphysica, quia post physicam resolvendo occurrit [Thomae de Aquino (1959)].
} 
Thomas believes that metaphysics is occupied with the focal and uncomplicated causes (God, and more broadly - substantiae separatae) in the order of real existence (secundum rem), while in the conceptual order (secundum rationem) with that which is most general, shared by everything, everything that is, i.e. being as being and all of its significant properties. All this is conducted in accordance with the intellectual method of inquiry, i.e. from one truth the mind "constructs" and derives all plurality and diversity of cognition (secundum viam compositionis et inventionis). If so, metaphysics can be on the one hand validly assessed as the first philosophy that supplies principles to other sciences (as when transcending from singularity to plurality and from the most general of forms to more precise forms it initiates rational considerations inherent to these sciences). On the other hand it is equally valid to treat metaphysics as studied knowledge and as knowledge acquired subsequent to other studies (which is revealed by the very term "metaphysics" or "transphysics" - "after physics"). Its inherent modus procedendi - intellectual considerations - is also the end, the final point of rational consideration, which starts with numerous data and derives from them one truth, i.e. which constructs from multiple detailed data one general knowledge, reducing complexity to that which is simplest and least complex (secundum viam resolutionis). The final point of reasoning is the subject of intellectual reasoning, that which is the most general and the most simple, that which is shared by all forms of existence (communia omnibus entibus) - being as being and substantiae separatae. Scientia divina (in other words: metaphysics) is in turn concerned with these forms of existence. This is why Thomas formulated the hypothesis that all forms of intellectual reasoning explained by reduction (ratio resolvens) lead ultimately to intellectual reasoning inherent to metaphysics and end with it. This is the reason behind the sequence of natural sciences and metaphysics in the order of human cognition.

However, we must mention here an important objection concerning the methodological specificity of metaphysics as a discipline with which intellectual considerations and not rational reasoning in the above sense are inherently linked (consideratio intellectualis, intellectualiter procedere): We say that divine science proceeds intellectually not as though it makes no use of reason, moving forward from principles to conclusions, but because its reasoning most closely approaches intellectual consideration and its conclusions are closest to its principles 9 .

Thomas clearly states that ascribing intellectual reasoning to metaphysics does not mean that discursive reasoning, advancing from cause to effects (from empirical data to general conclusions) is not conducted in its realm. It means, however, that its reasoning especially resembles (resembles as much as possible - propinquissima) intellectual considerations, and the conclusions drawn from these considerations are derived as closely as possible to its previously assumed principles. This qualification is linked with the fact that according to Thomas none of the three procedures distinguished by him: procedere disciplinaliter (disciplinalis modus), procedere rationabiliter (rationabilis modus) and procedere intellectualiter (intellectualis modus), is ascribed solely to one science in a way that prevents it from being used by a different science. Rather, it is that one method dominates a particular theoretical science (hence the

\footnotetext{
${ }^{9}$ In Boetii De Trinitate, pars 3, q. 6, a. 1, c: Intellectualiter procedere non attribuitur scientiae divinae, quasi ipsa non ratiocinetur procedendo de principiis ad conclusiones, sed quia eius ratiocinatio est intellectuali considerationi propinquissima, et conclusiones eius principiis [Thomae de Aquino (1959)].
} 
differentiation between metaphysics and natural sciences based on methods - Thomas in both cases utilizes the formula: in ipsa maxime observatur modus...). For example, in mathematics procedere disciplinaliter is the dominating method, i.e. procedere demonstrative et per certitudinem, for natural sciences - procedere rationabiliter, or ratiocinando, discurrendo vel ex effectibus in causa, vel ex causis in effectus, for metaphysics - for the aforementioned reasons - procedere intellectualiter, or per cognitionem principiorum.

This is why, although demonstrating the truth (procedere demonstrative) and attaining certainty (procedere per certitudinem) is inherent to all theoretical sciences, nonetheless it is foremostly ascribed to mathematics: Mathematical science is said to proceed according to the mode of learning (disciplinaliter), not because it alone does so, but because this is especially characteristic of it ${ }^{10}$. This is because it provides greater certainty than physics and metaphysics ${ }^{11}$. On a different note, knowledge of the hierarchy of theoretical sciences established by Aristotle and Thomas's numerous references to his preference of metaphysics, this conclusion can be assessed as highly unobvious. We will later see that in other works the position of knowledge with the highest level of certainty, prevailing in this matter over all theoretical sciences, is linked by Thomas with theology - but revealed theology and not metaphysics understood as philosophical theology. We must however honestly state that here, in his commentary to Boethius, Thomas clearly affirms that mathematical investigations and their results appear to be more certain than what can be known via other branches of science ${ }^{12}$. Substantiation for mathematics' greater certainty can be different in reference to different branches of science. Natural sciences explore that which is individual, material and progressing to a greater extent than mathematics and that is why they must deal which a greater number of variables and unknowns, while metaphysics deals with what is accessible by "ordinary" human cognition (and in that sense is less verifiable) to an even smaller extent than mathematics, as it is to an even greater extent distant from the senses - from which all cognition starts.

According to Thomas Aquinas rational behavior dominates natural sciences and is here used to the greatest extent, which does not make it inherent solely to these sciences: We say that natural science proceeds rationally, not because this is true of it alone, but because it is especially characteristic of it ${ }^{13}$. This rational modus procedendi differs from the "logical" one ("scientific" - modus disciplinalis), inherent mainly to mathematics, as it is not solely conceptual in nature, i.e. in the argumentation process it also refers to things themselves and their exterior causes, and not only to their causes or formal reasoning and their innate terms or definitions. And this is why - taking under consideration the specifics of human cognition (i.e. cognition innate to rational beings) which follows the path from that which is felt by the senses (from what is available and obvious to a greater extent) to that which is outside the reach of the senses (more obvious per se but not to us) and which, additionally, goes in reasoning from one factual state to the next, from cognition of

\footnotetext{
${ }^{10}$ In Boetii De Trinitate, pars 3, q. 6, a. 1, c - ad secundam quaestionem: Disciplinaliter procedere attribuitur scientiae mathematicae, non quia ipsa sola disciplinaliter procedat, sed quia hoc ei praecipue competit [Thomae de Aquino (1959)].

${ }^{11}$ Cum enim mathematica sit media inter naturalem et divinam, ipsa est utraque certior (ibidem).

${ }^{12}$ Mathematica consideratio est facilior et certior quam naturalis et theologica (ibidem).

${ }^{13}$ In Boetii De Trinitate, pars 3, q. 6, a. 1, c: Attribuitur ergo rationabiliter procedere scientiae naturali, non quia ei soli conveniat, sed quia ei praecipue competit [Thomae de Aquino (1959)].
} 
a single object to another (e.g. from effect of the cause to grasping the cause) - we can state that natural sciences are most congruent with the human mind, and most attuned to the way it operates ${ }^{14}$.

The previous remark concerning the primacy of mathematics in relation to other sciences in the category of certainty, and the conclusion indicating the primacy of natural sciences in the category of being attuned to the "natural" manner in which the mind operates, can cause us to question - or at least relativize - Thomas Aquinas's conviction concerning the primacy of metaphysics in relationship to other sciences, expressed in the way Thomas consequently calls it the first philosophy. Undoubtedly this forces us to once more reconsider the criteria of this "first" nature: perhaps that which in abstracto and simpliciter (generally and unconditionally) is first, in concreto and secundum quid (in particular and under certain conditions) - does not have to be first. In other words: in the system of knowledge constructed by Thomas Aquinas metaphysics is first in its essence (essentaliter and per se), especially from the point of view of its subject matter, but other sciences can be first accidentally (per accidens), due to, i.e., the reliability of their methods, the certainty of results or being attuned to the way the human mind operates. Each of these hypotheses seems permissible, and Thomas himself invites us to consider them, by treating metaphysics not only as the first philosophy but also - complementarily - as the final knowledge, "later" in various ways than other sciences.

To complete the topic we have been analyzing from various angles, Thomas's considerations can be compared with a certain epistemological solution to the problem of "circularity" of argumentation in reference to the status of metaphysics among other sciences, proposed at the turn of the 13th century by Duns Scotus: Although metaphysics comes last in the order of learning it is still - as Avicenna wanted it - first in the order of clear and distinct cognition. The subject of metaphysics is being as well as other common properties, thus being is what is perceived in a clear and distinct manner first. This is why geometry learns of lines only that they have length but no width. A geometrician does not have to know what quantity is, but a metaphysician should determinate this concept, as his task is to confirm the principles of other sciences. This is why metaphysics is first in the order of clear and distinct cognition but last in the order of learning. And this is why Avicenna states that there is no vicious circle in knowing and studying sciences even if other sciences are studied before metaphysics while metaphysics, in turn, allows one to know the principles of other sciences ${ }^{15}$.

In the first version of his Oxford commentary to Peter the Lombard's Sentences, Duns Scotus suggests a solution to Avicenna's dilemma (linked to the ambiguous position of metaphysics among other sciences - as prima yet at the same time ultima).

\footnotetext{
${ }^{14}$ Propter hoc scientia naturalis inter alias est maxime hominis intellectui conformis (ibidem).

${ }^{15}$ Lectura Oxoniensis I d. 3 p. 1, q. 1, 76: Metaphysica, licet sit ultima ordine doctrinae, tamen est prima ordine distinctae cognitionis, sicut vult Avicenna. Sed metaphysica est de ente et de aliis communibus, igitur ens erit primo distincte cognitum. Unde geometria cognoscit de linea quod sit longitudo sine latitudine; nec oportet geometricum scire utrum sit quantitas, sed hoc habet metaphysicus dicere, cuius est certificare principia aliarum scientiarum. Unde metaphysica est prima in ordine distinctae cognitionis, sed est ultima in ordine doctrinae. Et ideo dicit Avicenna quod non est circulus in cognitione scientiarum, licet aliae scientiae prius acquirantur quam metaphysica, et metaphysica faciat cognoscere principia aliarum scientiarum [Duns Scotus (1960)].
} 
Scotus suggests solving the matter with the help of the theory of knowledge. We only need to distinguish distinct cognition (cognitio distincta) from indistinct cognition (cognitio confusa). Distinct cognition contains knowledge of the first principles of knowledge and is inherent to metaphysics. Indistinct cognition is carried out without knowledge of the first principles and is inherent to other sciences in their routine research practices. One who studies geometry does not need to know what quantity is; he is effective in his field and may reveal new knowledge concerning linearity without a need to consider the first principles of the objects he is researching. All the more so as his research does not need to be preceded by a reflection concerning being as being (according to Duns being is the primum distincte cognitum). The researcher requires only cognitio confusa, without reference to the principles with levels of generality inherent to metaphysics. It is the task of metaphysics to acquire certainty regarding the first principles of existence - or cognitio distincta.

From here Duns Scotus draws the conclusion that we may disregard the circularity of reasoning argument concerning the relationship of metaphysics and other sciences, as - on the one hand - they remain in mutual correlation, but - on the other - they do so on different epistemological levels. Other sciences, especially natural sciences, precede metaphysics in case of indistinct knowledge, but do not reach the first principles, thus providing only data derived from cognitio confusa. Metaphysics, however, supplies the first principles; that which belongs to the realm of distinct cognition. As far as this cognition is concerned, metaphysics is first: other sciences gain access to this knowledge only if they refer to the principles supplied and confirmed by metaphysics. Yet they may conduct their research independently; may reveal new truths in the realm of indistinct cognition. This is useful for understanding and comprehensible explorations conducted with the help of metaphysics - which, however, does not need this type of cognition in order to reach distinct knowledge concerning its first principles. In short: according to Duns Scotus metaphysics does not depend on other sciences within the scope of principles which guarantee cognitio distincta, while other sciences are not dependent on metaphysics as far as cognitio confusa is concerned. This solution offers support for the hypothesis that metaphysics is first in regard to other sciences (on the level of distinct cognition - in ordine distinctae cognitionis), and is simultaneously subsequent - on other levels and in the doctrine understood by our minds (in ordine doctrinae). E. Gilson, a renowned expert on medieval philosophy, portrays the issue in the following manner: since the ordinary order of cognition spontaneously starts with the unclear perception of an empirical concrete and not the clear perception of that, which is most universal (being as being), then metaphysical knowledge is acquired last (dernière acquise), but is simultaneously the first that is, sensu stricto, perceived clearly (première connue) ${ }^{16}$. We may thus state that although Duns Scotus follows a different route and uses different terminology, he comes to the same conclusions as Thomas Aquinas.

An honest reflection concerning the question of what is first in the context of Thomas Aquinas's considerations on the status of metaphysics among other sciences should obligatorily also take under consideration the comparison of metaphysics understood as scientia divina (knowledge concerning the divine - "philosophical theology" as Thomas Aquinas calls it), with theology in the religious sense - "revealed

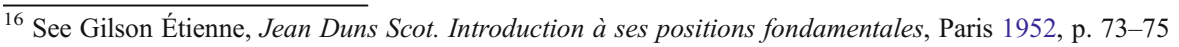


theology" (called by Aquinas sacra doctrina or theologia sacrae Scripturae). The philosopher believes that revealed theology is also a science - a science that must exist by necessity (por. Summa theologiae I, q.1 a.1 and 2; Scriptum super Sententiis. q.1 a.1 and a.3, qc. 2), and is an independent, separate science - as far as source, methodology and in part subject matter are concerned - from metaphysics or other theoretical sciences (praeter philosophicas disciplinas). In the commentary to Boethius's De Trinitate, Aquinas states: There are two kinds of theology or divine science ${ }^{17}$. Then explains in detail why even when both theologies agree to discuss the same subject matter ${ }^{18}$, they do so in diversimode. Some researchers seem to question this dissimilarity and deny philosophical theology a distinct status due to the postulated or actual coherence of Aquinas's philosophy, where it is impossible to radically distinguish the philosophical from the theological. This conclusion can be reached, inter alia, based on some of the statements formulated in Gilson's monumental work on Thomism ${ }^{19}$. The best answer to these types of objections, it seems, is to indicate - as Leo Elders had done, polemizing with Gilson ${ }^{20}$ - the above sources in which Aquinas clearly states that there are two types of theology and sacra doctrina, revealed theology, is necessary as distinct from metaphysics - or theology practiced on philosophical foundations. There is a wide variety of literature concerning the differences between these two types of theologies (although not always theologies other that revealed theology are understood as equivalent to metaphysics), as the problem is subtle and multidimensional. In this article I will limit myself to only one angle of the discussion, i.e. the arguments concerning the sense of the hypothetical primary nature of revealed theology when compared with metaphysics as philosophical theology. In confrontation with sacra doctrina, metaphysics appears to lose its position as first in the order of sciences, even if it remains philosophia prima due to the knowledge attainable only with the help of rational epistemological tools.

Metaphysics deserves the rank of the first philosophy, inter alia, because its subject matter is the first cause of existence. In a commentary to Aristotle's Metaphysics, Thomas states: dicitur autem prima philosophia inquantum primas rerum causas considerat (In Metaphysicorum Aristotelis..., prooemium) [Thomae Aquinatis (1950)]. Yet revealed theology is also considered a source of knowledge concerning the primary causes (as it is concerned with God - seen from the biblical perspective as the creator, and therefore the effective cause of all existence). Since both disciplines validly consider the primary cause of existence, primacy belongs to the discipline which provides a better explanation. Thomas Aquinas states that even if metaphysics as philosophical theology considers God to be the primary cause (as ontology metaphysics should encompass also this specific form of existence), it does not do so as exhaustingly or as adequately or as authoritatively as sacra doctrina - theology derived from the Holy Bible. He favors the argument according to which if knowledge about God could be achieved solely en route intellectual reasoning (with the help of metaphysics), only a select few would grasp this knowledge -

\footnotetext{
${ }^{17}$ In Boetii De Trinitate, pars 3, q. 5, a. 4, c: Sic ergo theologia sive scientia divina est duplex [Thomae de Aquino (1959)].

${ }^{18}$ Utraque autem est de his quae sunt separata a materia et motu (ibidem)

${ }^{19}$ Gilson uses such terms as l'accord de fait or l'admirable unité de l'oeuvre philosophique et de l'oeuvre théologique de saint Thomas. See Gilson Étienne, Le thomisme. Introduction au système de saint Thomas d'Aquin, Paris 1922, p. 29

${ }^{20}$ See Elders Leo, The Philosophical Theology of St. Thomas Aquinas (Studien und Texte zur Geistesgeschichte des Mittelalters, Bd 28), Leiden 1990, p. 2-3
} 
and the process would take a long time, with various mistakes made ${ }^{21}$. Revealed theology would, in contrast, guarantee universal, fast and certain access to knowledge about God as the first cause. From this point of view - as long as we identify the first cause of being with God - it is revealed theology, not metaphysics, which deserves to be first in the system of human knowledge.

We may also believe that one of the main arguments for the antecedence of metaphysics among other sciences - that it provides the first principles for these sciences - loses its relevance in reference to revealed theology, as theology draws its prima principia not from any human science that would be contain primary or "higher" knowledge, but - in accordance with its name - directly from supernatural revelation. In accordance to the formula provided by Thomas Aquinas in his commentary to Peter the Lombard's Sentences: This doctrine has the articles of faith for its first principles. The articles of faith are known through themselves by the infused light of faith to those who have faith ${ }^{22}$. Thus the first principles of revealed theology are simply articles of faith, which are obvious only in reference to faith and for the devout. The predisposition to faith - the superinfused light of faith (lumen fidei infusum) - substitutes the natural human disposition known as the intellectus principiorum - the ability to intuitively grasp the first principles of cognition, a primary metaphysical principle characteristic of scientia maxime intellectualis, as its most significant modus procedendi are reasoning or intellectual considerations (consideratio intellectualis). We must admit that certain renowned experts on Thomas Aquinas's works, such as M.-D. Chenu, emphasize that despite everything revealed theology maintains its rational character and is not to be identified with pure fideism; although the reasoning it defers to is enlightened by faith (ratio fide illustrata), it remains a reasoning (la raison théologique ... demeure raison $)^{23}$. This is why consideratio intellectualis, the method of reasoning Aquinas deems proper for philosophical theology - in other words metaphysics as a theoretical science - is extended by Chenu to encompass sacra doctrina, or revealed theology ${ }^{24}$. Yet due to its primary and necessary sources and its inextricable link with faith which illuminates the mind, revealed theology appears to be radically independent from metaphysics (to a greater extent than any other knowledge), and its inspirations to be first are based, inter alia, on the conviction of its exceptional, stronger than in any other science, foundations (since its first principles are identical with authoritative revelation - with divine knowledge stemming from God $)^{25}$.

Doubts may however be raised by the fact that the aforementioned foundations are not liable to rational confirmation, are not subject to universal cognition and intersubjective verification since articles of faith as the first principles of revealed theology are ex definitione acknowledged by a limited group of people who have been superinfused with the light of faith. R. McInerny, inter alia, notices this limitation in

\footnotetext{
${ }^{21}$ Summa theologiae I, q. 1, a. 1, c.... a paucis, per longum tempus et cum admixtione multorum errorum [Thomae Aquinatis (1888)] Cf. also: Summa contra Gentiles I, cap. 4 [Thomae Aquinatis (1918)].

${ }^{22}$ Scriptum super Sententiis q. 1, a. 3, qc. 2, ad 2: Ista doctrina habet pro principiis primis articulos fidei qui per lumen fidei infusum per se noti sunt habenti fidem [Thomae Aquinatis (1929)].

${ }^{23}$ Chenu Marie-Dominique, La théologie comme science au XIII sièclle, Paris 1957, p. 88

${ }^{24}$ Cf. ibidem, p. 91

${ }^{25}$ For a great study concerning this issue see, inter alia, J.- P. Torrell. See Torrell Jean-Pierre, Le savoir théologique chez saint Thomas (in :) Revue Thomiste 96 (1996), p. 355-396
} 
this subtle analysis of the relation between believed truths and known truths. According to the researcher revealed theology, as a science distinct from philosophical theology (metaphysics), has a limited reception as it is impossible without faith, even if different from faith itself ${ }^{26}$. Acknowledging that sacra scriptura reveals the truth about God is its' condition and foundation. Those who do not believe may question the validity of these foundations and the certainty of knowledge built upon them. Thomas Aquinas sidesteps these doubts in part, and in part attempts to refute them by stressing that revealed theology surpasses all other sciences not only because it pertains to the most perfect of subjects (propter dignitatem materiae), but also because it offers the most certainty (propter certitudinem). It is still assessed as certain that knowledge gained solely with the help of the light of the human mind (ex naturali lumine rationis humanae) - including knowledge derived from the first principles of metaphysics - may be unreliable, as the human mind is always susceptible to error. Certainty of knowledge gained with the help of revealed theology (ex lumine divinae scientiae) may be questioned not because it may objectively be false, but solely because this certainty is perceived as obvious and is not understood adequately due to cognitive feebleness, the limited "capacity" of our minds: Nothing prevents it from being the case that what is more certain by its nature is less certain to us, and this because of the weakness of our intellect ${ }^{27}$. Thomas Aquinas in these cases usually referred to Aristotle's comparison of the mind to an owl whose sight is helpless during the day and which cannot see that which is the brightest. However, here I would rather not occupy myself with the question of the assumed primacy of revealed theology in this respect.

It seems to be an axiom for the reflection on metaphysics that its inspiration was to assume first position of metaphysics in the system of science; metaphysics was supposed to be first and reveal that which is first. This approach preordained its specific nature and rank - it was no coincidence that it was called the first philosophy. I attempted to show the dominating tone of Thomas Aquinas's considerations concerning the status of metaphysics in relation to other sciences. And we may affirm that metaphysics, in his understanding of it, is in many cases "first". Yet the conclusions stemming from my analysis are not unambiguous: primacy of metaphysics may generate various difficulties (the problem of "circularity" of argumentation). Furthermore, it may be even questioned - in certain areas and in reference to certain disciplines. Thomas Aquinas was not blind to the problematic side of the first philosophy. And the search for an answer to the question "What is first?" - also in the context of classic metaphysics - is still worth the effort.

Open Access This article is distributed under the terms of the Creative Commons Attribution License which permits any use, distribution, and reproduction in any medium, provided the original author(s) and the source are credited.

\footnotetext{
${ }^{26}$ Cf. McInerny Ralph, St. Thomas Aquinas, Notre Dame, London 1982, p. 143-146, 167-169

${ }^{27}$ Summa theologiae I, q. 1, a. 5, ad 1: Nihil prohibet id quod est certius secundum naturam esse quoad nos minus certum propter debilitatem intellectus nostri [Thomae Aquinatis (1888)].
} 


\section{References}

Avicenna (1977). In S. Van Riet (Ed.), (Ibn Sina) Avicenna Latinus. Liber de philosophia prima sive scientia divina (Metaphysica) $I$ - IV. Louvain - Leiden.

Chenu, M.-D. (1957). La théologie comme science au XIII siècle. Paris.

Duns Scotus, I. (1960). In C. Balič (Ed.), Lectura in librum primum Sententiarum (Lectura Oxoniensis), Prologus et distinctiones a prima ad septimam, Opera omnia, $t$. 16. Vaticana: Civitas.

Elders, L. (1990). The philosophical theology of St. Thomas Aquinas (Studien und Texte zur Geistesgeschichte des Mittelalters, Bd 28). Leiden.

Étienne, G. (1922). Le thomisme. Introduction au système de saint Thomas d 'Aquin. Paris.

Étienne, G. (1952). Jean Duns Scot. Introduction à ses positions fondamentales. Paris.

McInerny, R. (1982). St. Thomas Aquinas. London: Notre Dame.

Thomae Aquinatis, S. (1888). Pars Prima Summae theologiae, Opera omnia iussu impensaque Leonis XIII P. M. edita. Romae: Editio Leonina. t. 4.

Thomae Aquinatis, S. (1918). Summa contra Gentiles, lib. 1-2, Opera omnia iussu Leonis XIII P. M. edita. Romae: Editio Leonina.

Thomae Aquinatis, S. (1929). In P. Mandonnet (Ed.), Scriptum super libros Sententiarum magistri Petri Lombardi, $t$. 1. Parisiis: P. Lethielleux.

Thomae Aquinatis, S. (1950). In M. R. Cathala \& R. M. Spiazzi (Eds.), In duodecim libros Metaphysicorum Aristotelis expositio. Taurini - Romae: Marietti.

Thomae de Aquino, S. (1959). In B. Decker (Ed.), Expositio super librum Boethii De Trinitate. Leiden: E.J. Brill.

Torrell, J.-P. (1996). Le savoir théologique chez saint Thomas d'Aquin. Revue Thomiste, 96, 355-396.

Wippel, J. F. (1984) Metaphysical themes in Thomas Aquinas. Washington. 